\title{
BRIDGING HISTORICAL PERIODS. A SELECTION FROM THE WRITINGS OF GYULA RÉZLER
}

\author{
ESZTER BARTHA ${ }^{l}$
}

(Válogatás Rézler Gyula 1932 és 1999 között megjelent írásaiból. Ed. by Pál Péter Tóth, Budapest, Gondolat Kiadó, 2011, 302. p.)

Julius Rézler's name is known to the Hungarian academic world but we do not have yet a full picture of the scholar's work. The book under review is a second selection of the articles which Rézler wrote that were published predominantly in Hungary. It was published on the occasion of a conference organized at the Hungarian Academy of Sciences to commemorate the 100th anniversary of the birth of the scholar (who was himself a member of the Hungarian Academy). The volume makes an important step towards the re-discovery of Julius Rézler, demonstrates the timeliness of his thoughts on the place of Hungary in the world and marks his place in Hungarian sociology.

Julius Rézler was born in a difficult historical period but the geopolitical circumstances of his era facilitated re-evaluation of the development of and opportunities for Hungary. The circumstances of his youth were determined by the collapse of the Austro-Hungarian Monarchy, the loss of territories concluded by the Treaty of Trianon and the faith that a nationally homogenous, strong, Christian Hungary could provide a solution to the century-long culde-sac of Hungarian political-economic development. The articles, which he wrote as a student of the Pázmány Péter University (today the Eötvös Loránd University of Sciences), reflect this conviction, which he shared with many other of his contemporaries. In his early political writings he argued that youth has a distinguished role in the formation of new policies which could lead to the creation of the homogenous, strong nation state which he considered to be desirable at the time. He could not have foreseen the human and political

1 Eszter Bartha works at Eötvös Loránd University of Sciences, Faculty of Humanities, e-mail: barthaeszter@hotmail.com 
tragedies caused by Fascism, which lead to the consequent (and let's add, aggressive) political education of the youth.

We should evaluate the early political writings of Julius Rézler in the social context of his era but we cannot doubt his life-long commitment to the advancement of Hungary. He displayed sensitivity to social problems at an early age by calling for reductions in the high unemployment rate of young graduates (who often had to work at manual jobs), more transparency in the supposedly 'open' competition for administrative and other state positions and he also urged young people to be physically active and to train more. His early articles in the journal Magyar Egyetemi Híradó (Hungarian Graduate News) display his facility for writing, his sharp logic and his eye for detail, all of which are all hallmarks of a great thinker. Many of his thoughts were timely - such as his call to reduce the high rate of unemployment of young graduates or his criticism of young Hungarian graduates who refuse to study economics. But he also criticized the Hungarian estate system, which had feudal origins (he pointed out that Romanians had bought Hungarian land in Transylvania well before the Treaty of Trianon, and he blamed the shortsightedness and greediness of the contemporary Hungarian political elite for the loss of national territories). Rézler was possessed with political courage, which he proved on numerous occasions: he was engaged with politically taboo topics at a young age and his political writings were always driven by his sense of justice, his human and academic honesty and his objectivity.

Julius Rézler was however, first and foremost, an academic and not a politician. A substantial part of his prewar work was dedicated to the industrial working class and the elaboration of research methodology. He was critical of the work of contemporary Hungarian ethnographers (many of whom were his personal friends) because they lacked a sociological method and they replaced objective academic research and critical investigation with subjective descriptions. Their works were often silent about the arguments of other, 'opposing', social classes and they failed to state how widespread negative social phenomena (limiting the number of children in the family to one, poor nutrition, alcoholism or hopeless misery) were in contemporary Hungary. Rézler had a high opinion of Ferenc Erdei, a well-known Hungarian ethnographer, political thinker and sociologist, but he did not hesitate to point out the contradictions inherent in his writings and the inaccuracy of his definitions. The separation of ideology from science and the objectivity of method was part and parcel of Rézler's academic program - which he attempted to put into practice when he proposed a systematic survey of the industrial working class in Hungary. He drew this up strictly based on the scientific method: the survey includes the main characteristics of the settlements 
and the factories, the working-class society of the manufacturing industry, working conditions, the social policy of the factories, the representation of labor interests, the scale and type of workers' organizations, housing conditions, family types and size and the economic and cultural conditions of the working class. Rézler used this method to investigate the conditions of working people in the brick yards, the sugar mills, the ironworks and the textile industry. His important work from this period bears the title A magyar nagyipari munkásság kialakulása 1867-1914 (The Formation of the Large Industrial Working Class in Hungary, 1867-1914), and it is one of the lasting achievements of Hungarian sociology from the interwar period. He showed that it was possible to conduct systematic empirical research in Hungary on a topic which did not enjoy the support of the contemporary political elite. Rézler's sensitivity to his selection of sources should be stressed here - he studied and used police reports of workers' organizations in his work well before Edward P. Thompson did.

Julius Rézler urged the government to set up an interdisciplinary institute for the study of work and labor-related issues. He proposed that sociology, economics, law, political science and psychology be included as subjects of study for the institute. The Institute was established in 1943. Rézler employed András Hegedüs and Ferenc Sz $\square$ cs, who were members of the underground Communist resistance, although their political views were not known to Rézler at the time. From 1944 onwards the Institute served as a façade for anti-Nazi resistance. The Germans, however, had made lists - Hegedüs was arrested and Rézler had to go into hiding. The materials and the library of the Institute were torched by the Soviet troops who liberated the city from the terror regime of the Nazis.

Julius Rézler's sociology was for long time unknown in Hungary, which is why it is welcomed that the volume includes his work "Bevezetés a szociológiába" (Introduction to Sociology). Rézler sought to provide a synthesis of the theories that he introduced. The Marxist method was obviously an important influence on him because of its objectivity, its use of rigorous categories and its social Weltanschauung. It is to be regretted that the Communist regime, which was established after 1945, sought to exclude rather than include scholars like him, who were deemed unacceptable due to the dogmatic party line. I mention here his research entitled "Kiegyezés és Trianon: Szempontok a legújabbkori magyar történelem revíziójához" (The Austro-Hungarian Compromise and Trianon: Criteria for revisiting contemporary Hungarian history) in which he seeks to thoroughly revisit the national romantic idols of his youth. After the tragedy of Nazism, Rézler blamed the Austro-Hungarian Compromise for the sad failure of Hungarian 
liberalism. He argued that the Hungarian nation was possessed of healthy political sense but had refused to make a compromise with the declining Habsburg Empire. The Compromise was forced upon the Hungarian nation by a narrow group of elites which benefited from the existence of the newly-organized Austro-Hungarian Monarchy. The Compromise, however, contradicted the national and economic interests of the country, and it helped maintain Hungary's economic dependence from the West. Rézler, however, limits the analysis here to the nation-state and he ignores the fact that Hungary's economic backwardness (as compared to Western Europe) goes back many centuries. The Austro-Hungarian Compromise resulted in credit being given to Hungary - and without credit, industrialization could only have happened at the price of the inhuman exploitation of the population, which we can see in the examples of Communist regimes. Rézler wrote much about the development of Hungarian industry and he argued that social policy should be part and parcel of national economic policy. He, however, did not answer the question of how a relatively poor country (whose population, industry and infrastructure suffered enormous damages in the Second World War as the last ally of Nazi Germany) could finance this policy. Perhaps it would have been useful to address the question of who should bear responsibility for the outcome - although the political activity of Julius Rézler after 1944 provides an answer to this question.

In 1945 Rézler published research about the advancement of the industrial working class in Europe, in the form of a book. At the time, Rézler was optimistic: he thought that the Hungarian Communist Party, which represented the triumphant working class, would seek to compromise with the bourgeoisie. He argued that the standard of living of the European industrial working class would catch up with that of the bourgeoisie. It is not Rézler's fault that this optimistic prognosis proved to be wrong, and when entering into the Cold War era the Eastern European Communist parties sought to eliminate the bourgeoisie, bourgeois life-styles and bourgeois ideologies rather than accept to peacefully co-exist with them. This can not be defended on the grounds that the Communist parties destroyed their left-wing opponents even more effectively than they eliminated the bourgeoisie (think of the sad history of fabricated trials against 'enemies of the state' and the attempt to render the dogmatized Marxist-Leninist ideology the only ideology in human sciences) even if we should bear in mind that, despite all of its political failures, Marxism created an internationally well-known intellectual school in Hungary.

Julius Rézler was eventually forced to emigrate: his friends warned him that he would be arrested and charged with espionage because of his brother, who taught at Harvard University. 
His involuntary emigration meant that his acknowledgement in Hungary was minimal for a long time. His works contradicted the Marxist-Leninist ideology of legitimation: he showed that the large "exploited" Hungarian industrial working class earned above the Hungarian average of the prewar years and many enterprises had implemented generous social policies. His re-discovery in Hungary started with the relative political liberalization of the Kádár regime. György Litván published fragments of an important work of his about Hungarian workers, and in 1972 the same scholar published a detailed study about literature on workers in the interwar period in the journal entitled Szociológiai Szemle (Sociological Review), in which he stated that most of the authors were not Communists.

The work of Julius Rézler is enough to create a place for him in Hungarian sociology, even if he did spend much of his life in the United States of America. He received American citizenship in 1957. After the change of regime he lectured at several Hungarian universities. He was loyal to his social commitments in the US too - he studied the impact of automation on workers and he argued that it had a negative influence on unskilled and semi-skilled workers. He also recognized the trend to decrease the influence of trade unions. It is important to note that trade unions have since decreased in numbers while there has been a notable increase in work-related stress. Dismissed workers have to content themselves with poorer working conditions and the lower wages of the service sector. Michael Burawoy developed a similar argument; namely, that globalization goes hand in hand with the fragmentation of the working class as capitalism develops towards hegemonic despotism, where the bargaining position of labor is weakened by the mobility of capital and the fragmentation of the working class. Julius Rézler also pointed out these likely developments of capitalism. Julius Rézler's activity in the field of arbitration may also be underlined. Arbitration is an American model of resolving disputes between employers and employees. Rézler was an arbitrator in the US, and he sought to popularize this model in Hungary. His keynote speech on the occasion of his inauguration as Member of the Hungarian Academy addressed the issue of arbitration. He helped organize MKDSZ (the Service of Mediation and Arbitration in Disputes between Employers and Employees) and preferred the term "mediation". Julius Rézler established a Foundation in Hungary which seeks to support PhD students and to facilitate the education of future mediators.

The published volume provides an illuminating selection of the academic writings of Julius Rézler and it shows us hitherto unknown writing. The selection of pieces reflects the high editorial standards and it also gives the attentive reader an important compass with which to navigate the scholar's 
life. At 90 years of age, after the death of his wife, Rézler was occupied with the thought of re-settling in Hungary. His commitment to his native country was facilitated by invitations to visit many Hungarian universities. He fulfilled his teaching duties with typical thoroughness and conscientiousness until his unexpected death in October 2001. His life is a metaphor of a contradictory chapter of Hungarian history; a fact which should not prevent us from acknowledging the unique life and work of a great Hungarian scholar. 